\title{
SURVEY OF RESULTS ACHIEVED ON GEOGRAPHY QUESTIONS ON FINAL EXAM FOR ELEMENTARY SCHOOL STUDENTS - SAMPLE ANALYSIS
}

\author{
Igor Leščešen', Dragan Dolinaj', Milana Pantelić \\ Received: August 28, 2017 | Accepted: November 5, 2017
}

\begin{abstract}
Evaluative function of the final exam provides insight into the educational achievements of students and assessment of the degree of achievement of general and specific standards of achievement. When analyzing the results of students per school year (2013/2014, 2014/2015, 2015/2016 and 2016/2017) it is clear that in last two year, pupils approach to combined test, and geography questions has got more serious. Te clear positive trend on total achieved percentage is noticed $(y=4.9 x+39.5)$. Same trend is noticed when results of each individual questions are analyzed. Even though our results show that boys achieved better results than girls, which is in contrast with state average, independent sample T-test results has shown that there is no statistically significant difference between results acquired by boys and girls. Although the final exam and the success of the elementary school are characterized by certain shortcomings, it is a good thing that they jointly contribute to the enrollment of students in high school because they compensate for their mutual shortcomings. However, it is important to make efforts to improve the quality of the assessment and the final exam, so that the education system is more equitable than it is currently
\end{abstract}

Key words: Geography, Combined test, Methodology, Final exam

\section{INTRODUCTION}

Apart for modern society, geography also has a great importance for the educational system of the Republic of Serbia. In modern times, geography is one of the central subjects in the national educational system because the synthesis of the spatial complex of geosphere responds to the requirements of the $21^{\text {st }}$ century, as it educates pupils interdisciplinary thinking, sustainable development, as it also applies and integrates modern technologies into the educational process (Pejnović, 2008),

Department of Geography, Tourism and Hotel Management, University of Novi Sad, Trg Dositeja Obradovića 3, 21000 Novi Sad, Serbia; Contact: igorlescesen@yahoo.com 
In many of European countries curricula, geography has an applicative-educational role as it develops the skills necessary for intelligent prediction of problems, visualization and different strategies of solutions that enable the preservation of quality of life and longevity (Curić et al., 2007; Kolenc Kolnik, 2011; Vuk et al. 2012).

When external final exam was introduced into the Serbian educational system it provided more reliable and objective results of pupils' educational achievements. Results collected by these exams allow us to measure actual student achievements and their comparison with the certain standards. Systematic analysis of pupils achievements from individual subjects allow for better insight into the achievement of these standards, detection of factors that affect pupils achievement, but also opens space for targeted learning and teaching interventions. The results of these tests should be cautiously analyzed and put in the appropriate context. Also, it should be noted that pupils' achievements are only one segment of the quality of the education system. In evaluating the system, it is important to determine the quality of teaching, the correlation of the quality of teaching and pupils achievements and, in particular, the contribution that teachers have to progress of pupils toward achievement.

The final exam at the end of compulsory education is prescribed by the Law on the Basis of the System of Education („Службени гласник PC“, бр. 72/2009, 52/2011, 5572013), and it was first conducted in June 2011.

Many European countries adopted External examination as a good evaluation of knowledge gained by pupils at the end of elementary school. In Bosnia and Herzegovina according to Article 25 of the Law on Primary Education ("Official Gazette of the Canton of Sarajevo" No. 10/04, 21/06, 26/08 and 31/11), the pupils, after completing the nineyear elementary school, place the External exam. External exam examines the knowledge, skills and skills acquired during the nine year basic education and training. First test was undertaken in 2012/2013 school year (http://www.pztz.ba/Page.aspx?id1=43). In Montenegro first external testing was conducted in 2013. External examination at the end of the third cycle of elementary school is a standardized external examination school achievements of students at the end of elementary school education. Such a decision was found foundation in the Law on Primary Education and Training, Art. 56 ("Sl. list RCG", br. 64/02 od 28. 11. 2002, 49/07 od 10. 08. 2007. i 45/10 od 04. 08. 2010). At the end of the third cycle, an external check is performed knowledge of students from: Montenegrin - Serbian, Bosnian, Croatian and Literary, Mathematics and one subject selected by the pupil from the list of compulsory subjects and studied in the III cycle (chemistry, physics, biology, history, geography and foreign language). The first State exam in Croatia, as a standardized measurement and evaluation of knowledge and skills after completion of elementary education was conducted in 2010 (Vuk et al., 2012). And it is standard since then. Since last reform in Hungary, in 2005, the final secondary-school examination (érettségi vizsga) takes place in three compulsory subjects (Mathematics, Hungarian and History) and two electives (Foreign Languages, Chemistry, Physics, Geography, Biology, etc.) (Education system Hungary, 2015).

The final exam at the end of elementary education consists of three tests (a test in Serbian/mother tongue, mathematics and combined test), and it examines the degree of achievement of general and specific standards of achievement. It is required for all stu- 
dents at the end of the eighth grade, and if a student does not enter the exam, he/she cannot get a certificate of completed elementary education.

Program of the final exam is determined by the competencies expected of students at the end of elementary school. Expected achievements are based on the content of curricula and general standards of achievements - educational standards for the end of compulsory education for students who have completed primary school. On the final exam tests all the competencies described in the educational standards for the subjects Mathematics, Serbian language, or native language, Biology, Geography, History, Physics and Chemistry can be examined. The lists of standards are set in the Rule book on general standards of achievement - educational standards for the end of mandatory elementary education (Sl. Glasnik RS, 2010).

For the final exam in elementary school, students must prepare for the tests in Serbian language, or mother tongue, in mathematics, but in the 2013-2014 school year the Ministry of Education, Science and Technological Development of Republic of Serbia in cooperation with the Institute for Education Quality and Evaluation established combined test, a test that estimates the knowledge of the five new subjects. Combined test examines competence in the natural and social sciences and includes content in the curriculum of Biology, Geography, History, Physics and Chemistry. The amount of individual subjects in a combine test (number or percentage of tasks) is structured according to the percentage of representation in the elementary school curriculum from the fifth to eighth grade (Sl. glasnik RS, 2014).

In Croatia, tests that pupils solve on the final exam are based on processed curricula and competences envisaged education standards. The structure of the final exam make unpublished requirements (since there are the preparatory tasks to exercise) and containing from 20 to 40 tasks depending on the estimated weight and the type of exercises. Within each of the subject tasks are distributed according to the level of the standards. The achievement of these standards is tested (Sl. glasnik RS, 2014. The introduction of the combined test in the final exam program is accompanied by numerous controversies. Nevertheless, according to official data from the website of the Ministry of Education, Science and Technological Development of Republic of Serbia, the students have recorded the highest number of points by solving this test in last four years (ĐurićZdravković et al., 2015; http://www.mpn.gov.rs/).

\section{MATERIAL AND METHOD}

The survey was conducted on a sample 439 pupils that of both sexes that have finished VIII grade with final exam, from two elementary schools, "Petefi brigade" Kula and "Aleksa Šantić" Stepanovićevo. As the results published by Institute for Evaluation of Quality of Education and Education show that, in total girls, achieve better results at combined tests. This hypothesis was tested on geography questions. The sample was represented with 224 boys (51\%), and 215 girls (49\%). Geography questions on combined test were divided into three levels: basic, intermediate and advanced. Requirements for each level are: 
- Basic level: Applies and interprets different sources with geographic information (geographic maps, geographic models, GPS, journals, scientific literature, statistics, internet) for planning and organizing different activities. It uses basic knowledge of geographic facts to understand, protect and rationally use natural and social resources in the local environment, in the Republic of Serbia and the surrounding countries.

- Intermediate level: Ability to cartographic display of geographical objects, phenomena and processes; understands the possibilities of applying modern technologies for planning and solving different personal and social needs. Independently explains the natural and social conditions and resources, and considers their impact on the natural and social-economic development of the Republic of Serbia and the region and actively participates in the valorisation of the geographical environment. Understands the contemporary problems in the local community and its state, proposes ways and participates in actions for their resolution.

- Advanced level: Pupils are able to use analogue and digital geographic maps, geographic and statistical research methods; compares and critically reviews relevant scientific data to explain geographic facts and their contribution to addressing social needs and problems. Critically analyzes and explains geographic links and relations between the solar system, geological development of the Earth, natural conditions and resources and respects the principles of sustainable development. It analyzes and explains the socioeconomic characteristics of the regional development of the Republic of Serbia and the regional whole in the world; anticipates and participates in regional development, protection and improvement of the local environment.

The basic function of the standard is to equalize the criterion, to know exactly what the measure is and what knowledge the learner has to possess after the primary school.

For statistical analysis standard descriptive statistical method was applied, such are arithmetic mean, standard deviation, and percentage of frequency, as well as the independent sample t-test for determining any statistically significant difference.

Geographical questions from combined test are presented in table 1. Results obtained by pupils on these questions were analyzed in this paper. Basic level questions are labeled Q1, intermediate Q2 and Q3 and Advanced level Q4. 
Table 1: Geography questions on combined tests
2013/2014
a) North America
b) Africa
v) Europe
g) Australia

Q1 Which continent has the biggest population density?

Q2 The Earth's sphere of water is called:
a) hydrosphere;
b) lithosphere;
v) atmosphere;
g) biosphere.

Q3 Link natural resources of Serbia with the areas in which they are located.

Enter the appropriate letter on the empty lines.
1. antimony
a) Carpathian oblast
2. -_- copper
b) Podrinje
3. oil
v) Kopaonik region
g) Vojvodina

Q4 Connect the continents to the climate zones they are in.

Enter the appropriate letter on the empty lines.
1. Europe
a) Tropical, southern tempered and southern cold belt
2. Africa
b) Tropical and the southern tempered
3. Australia
v) northern temperate and a northern cold
g) northern temperate, tropical and southern temperate

$2014 / 2015$

Q1 Consequence of the Earth's movement around the Sun is?
a) changes between day and night
b) changes of the seasons
c) the existence of the time zones
d) the apparent daily movement of the Sun

Q2 Which continent represents Anekumena?
a) Asia
b) Australia
c) Antarctica
d) North America
e) Africa

Q3 Connect each river with basins that they are flowing through.
1. South Morava
a) Zaječarska i Knjaževačka basin
2. Beli Timok
b) Vranjska and Leskovac basins
3. West Morava
v) Prijepolje and Pribojska basin
g) Požega and Čačansko-kraljevačka basin

Q4 Complete the sentence.

The name of the largest peninsula in Europe is compared to Serbia is located on side of the world. , and 
Q1 The mathematical elements of the map are:

a) population, settlements, economy;

b) cartographic network, map and framework of the map;

v) natural objects and phenomena;

g) legend and cartographic signs.

Circle the letter before the correct answer.

Q2 The Sun is ostensibly moving:

a) from west to east and this is the consequence of the Earth's Revolution;

b) from east to west, and this is the consequence of Earth Revolution;

v) from west to east and this is the consequence of the Earth's rotation;

g) from east to west and this is the consequence of Earth rotation

Q3 Each country is connected to the peninsula where it is located.

Enter the appropriate letter on the empty line.
1. _-_ Spain
a) Balkan peninsula
2. _-_ Italy
b) Scandinavian peninsula
3. Macedonia
v) The Pyrenees peninsula
4. _-_ Norway
g) Jiland peninsula
d) Apennine peninsula

Q4 By entering the plus sign (+) in the corresponding column, connect the river to the sea basin it belongs.

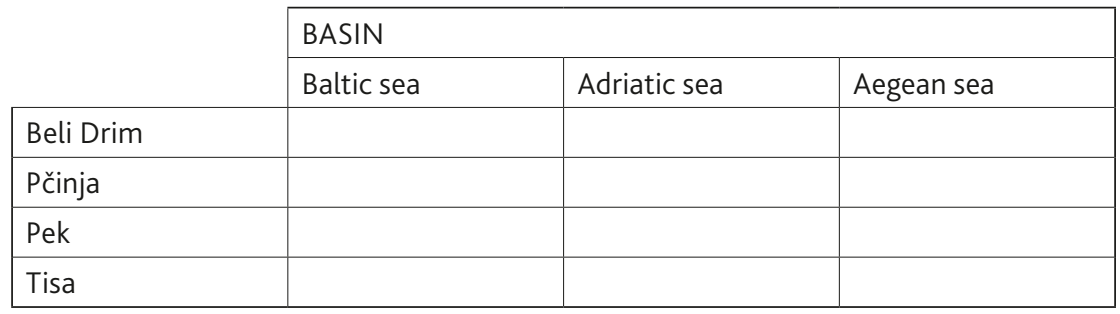

$2016 / 2017$

Q1 In the left column are listed the main sides of the world, and in the right their international mark.

Enter the appropriate letter on the empty lines.
1. south
a) $E$
2.
b) $\mathrm{N}$
3.
v) $S$
4.
g) W

Q2 By typing the (+) sign in the appropriate column, connect the state to the continent on which it is located.

\begin{tabular}{|l|l|l|l|}
\cline { 2 - 4 } \multicolumn{1}{c|}{} & South America & Asia & Africa \\
\hline Brazil & & & \\
\hline Nigeria & & & \\
\hline Japan & & & \\
\hline Argentina & & & \\
\hline
\end{tabular}


Q3 In addition to the name of the mountain top, type the name of the mountain on which it is located, as it has been started.

Pančićev vrh

Midžor

Cvijićev vrh

Đeravica

Crveni čot

Q4 Connect climate types with appropriate vegetation.

Enter the appropriate letter on the empty lines.

1. _-_ Continental climate a) lichen and moss

2. _-_ Sub-polar climate b) citrus fruits

3. _-_ Equatorial climate v) steppe

4. ___ Mediterranean climate g) jungle

d) savanna

\section{RESULTS AND DISCUSSION}

In figure 1 is presented a difference between requested \% that is set by Ministry of Education, Science and Technological development of Republic of Serbia, for the first and second question, which are defined as basic level the requirement was $80 \%$, third question is defined as intermediate level, requirement was $50 \%$, and forth question is defined as advanced level with requirement of $25 \%$. The results presented in Table 2 it is noticeable that only at the advanced level the requirement was met. For basic level difference between requested and achieved level was $7 \%$ and $2 \%$, in intermediate level $18 \%$ and for the advanced level the level was preceded for $5 \%$, this can be explained as in eight grade pupils learn about Serbia for entire school year and this question is from this part of curriculum, so the knowledge acquired from this year is more fresh in pupils memories.

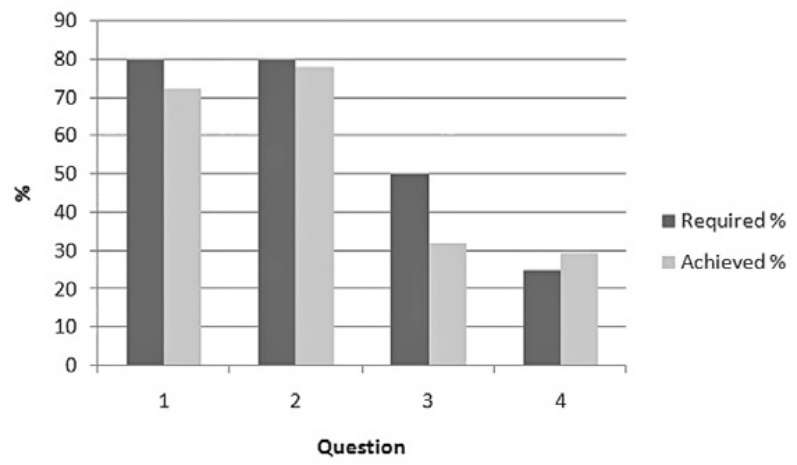

Figure 1: Relationship between Required \% and Achieved \% on geographical questions 
Even though, results shown in figure 1 are not satisfying, comparison of accomplished percentage acquired by pupils show a clear positive trend over last four years $(y=4.9 x+39.5)$ (Figure 2). For example, in 2013-2014 when combined test was first introduced average accomplished percentage on geography question was 49\%, in 2016-2017, this average percentage was $61 \%$.

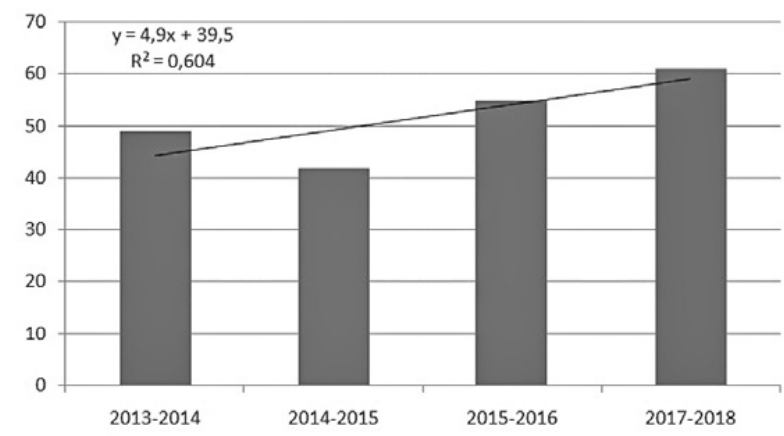

Figure 2: Trend of accomplished percentage in period 2013-2017

When analyzing the results of students per school year (2013/2014, 2014/2015, $2015 / 2016$ and 2016/2017) it is clear that in last two year, pupils approach to combined test, and geography questions has got more serious (Figure 3).

Basic level 1

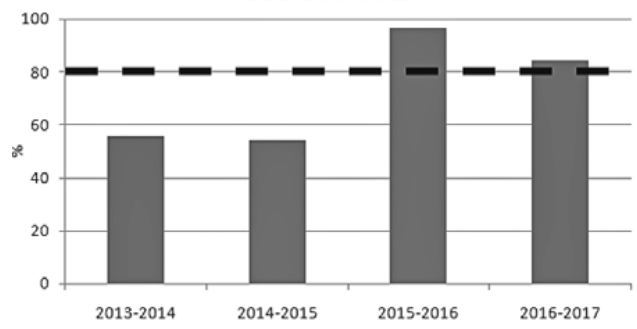

Intermediate level

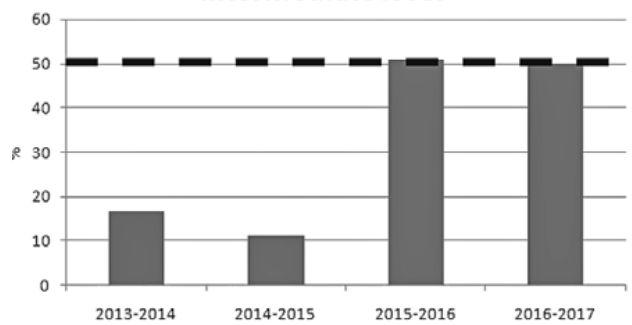

Basic level 2

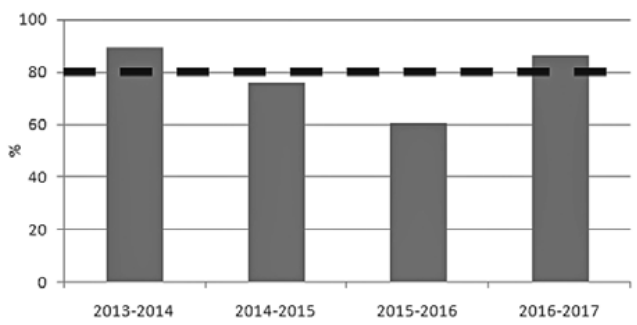

Advanced level

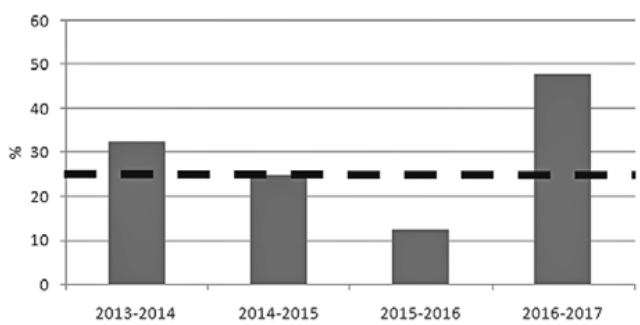

Figure 3: Comparisons of results obtained per total students per questions and per year * Interrupted line presents desired level of accomplishment (Basic level 1 and 2 - 80\%; Intermediate level - 50\%; Advanced level - 25\%) 
Same positive trend, that is presented in figure 2, is noticed in results of first basic level question $(y=12.90 x+40.27)$, intermediate level $(y=13.95 x+2.62)$ and advanced level question $(y=3.42 \times 5+20.95)$, only negative trend is noticed in the results of second basic level question $(\mathrm{y}=-2.524 \mathrm{x}+84.24)$.

In figure 3, we can see that for the basic level 1 questions only in last two years the desired \% was accomplished. These questions were from Human Geography in 2013/2014 and Physical Geography in 2014/2015, 2015/2016 and 2016/2017.

For the basic level 2 questions, in general, pupils had shown a better results, these questions were from the field of were Physical Geography in 2013/2014 and 2015/2016 and Human Geography in 2014/2015. In 2016/2017 this question was from the Regional Geography. Only in 2013/2014 and 2016/2017 pupils achieved the requested \%.

Desired \% for the intermediate level questions were achieved only in last two years, (2015/2016 - 51\% and 2016/2017 - 50\%) when questions were from Regional Geography and Geography of Serbia.

Advanced level question has shown that only in 2015/2016 the desired \% was not met. That year test had a Serbia related question as an advanced level question. In further text this issue will be addressed with more details.

Further analysis has shown that girls approached to this test more seriously as they accomplished better result than boys at first (13\% difference), third (3\% difference) and forth question ( $9 \%$ difference). Boys accomplished better results only in second question (16\% difference).

As in all previous years, girls are more successful than boys. The obtained differences for the benefit of girls were recorded at the republic, as well as at the district level, but also in most municipalities, regardless of the test (Извештај 2014; 2015; 2016). This is not the case in our investigated sample.

In table 2 is presented a comparison between accomplished percentage of boys and girls. It is noticeable that girls perform better at harder question (Q4-advanced level) than boys while boys achieved better results at intermediate level questions (Q3). From the results it is also shown that the results do not satisfy Ministry requirements, except the last question $(\mathrm{Q} 4)$.

Table 2: Achieved \% at different levels by boys and girls

\begin{tabular}{|l|c|c|c|c|c|c|c|c|}
\hline \multirow{2}{*}{$\begin{array}{l}\text { School } \\
\text { year }\end{array}$} & \multicolumn{4}{|c|}{ Boys } & \multicolumn{4}{c|}{ Girls } \\
\cline { 2 - 10 } & Q1 & Q2 & Q3 & Q4 & Q1 & Q2 & Q3 & Q4 \\
\hline $2013-2014$ & 63 & 94 & 23 & 49 & 48 & 85 & 11 & 16 \\
\hline $2014-2015$ & 42 & 73 & 11 & 6 & 66 & 80 & 12 & 45 \\
\hline $2015-2016$ & 99 & 73 & 51 & 8 & 94 & 49 & 51 & 18 \\
\hline $2017-2018$ & 79 & 91 & 75 & 43 & 90 & 81 & 25 & 53 \\
\hline Average & 71 & 82 & 40 & 26 & 75 & 73 & 25 & 33 \\
\hline
\end{tabular}

Independent sample T-test results show that there is no statistically significant difference between results acquired by boys and girls. It can be conclude that the differences between condition means are likely due to chance. 
Results of test obtained in first four years of applying combined test at the end of elementary school clearly show that more attention needs to be directed towards Regional Geography of Serbia (Table 1), maybe a change in the way this part of curriculum is presented. Acquired \% at these questions (Serbia) is really low, in 2013/2014 question regarding Serbia was Q3 and only achieved \% was only 17 of required $50 \%$, next year (Q3) only $11 \%$ of needed $50 \%$ was achieved, in 2016 (Q4), 13\% of $25 \%$ was achieved and in 2017 (Q3) the desired \% was achieved. Serbia related questions in 2013/2014, 2014/2015 and 2016/2017 were classified as intermediate level questions, and in 2016 this level was higher. This indicates that level of difficulty at these questions was a greater but considering that this part of curriculum is the freshest in pupil's minds, as well as it considers their own country a better results are required.

\section{CONCLUSION}

There is no statistically significant difference in results achieved by girls and boys, differences between these results are likely due to chance. On the other hand, results show that in researched sample of 439 pupils, over last four years, the requirements set by Ministry of Education, Science and Technological development of Republic of Serbia were not met.

Even thou, the number of question was small, in comparison to Geographical context in National curriculum for elementary school results of these test is very important to teachers because they clearly show in which areas changes need to be made for the purpose that students obtain better results.

It can be concluded that special care should be given to questions regarding Geography of Serbia as well as the questions that demand connecting, for example climate and vegetation. More explanations should be made in connections and causality between natural elements as well between nature and man. Pupils need to know why is something there and what it provides for the environment and its inhabitants, not just to know where is something, without further explanation and connections. For example, when they learn about Energetics of Serbia, besides teaching them where thermal power plants are located, they should mention why are they located there (because of coal basins) and then repeat how coal was created, why coal basins are they and create the whole picture to pupils. Another example, teacher should connect content from different fields and years, for example, when they teach in seventh grade about Himalayas they should repeat what type of mountains there are, and how did they become. Pupils will repeat what they learned, make a connection and as they are older, more serious and they will adopt the now knowledge and make it more permanent.

The final exam allows Ministry and teachers to obtain different types of data relevant to improving the examination process, supporting schools in the process of self-evaluation and evaluation, and monitoring the status indicators in education established by the National Education Council. Thus, in addition to being a useful tool for decisionmakers in the education system, these data are also useful mainly to teachers for planning and programming their future work. 


\section{REFERENCES}

Curić, Z., Vuk, R., Jakovčić, M., (2007). Kurikulumi geografije za obvezno obrazovanje u 11 europskih država - komparativna analiza, Metodika 8 (2), 444-466.

Đurić-Zdravković A-. Japundža-Milisavljević, M., Gagić, S. (2015). Postignuća učenika sa lakom intelektualnom ometenošću na probnom kombinovanom testu, Specijalna edukacija i rehabilitacija (Beograd), Vol. 14, br. 3. 303-318, doi. 10.5937/specedreh14-9238.

Education system Hungary | EP-Nuffic | 2nd edition February 2011 | version 2, January 2015.

Kolenec Kolnik, K. (2010). Applied geography and new goals of geography education in Slovenia, u: International Scientific Conference Applied Geography in Theory and Practice: Book of abstracts (ur. Lukić, A.), Geografski odsjek PMF-a Sveučilišta u Zagrebu, 57.

Official Gazette of the Canton of Sarajevo, No. 10/04, 21/06, 26/08 and 31/11.

Pejnović, D. (2008). Uloga geografije u osnovnom i srednjoškolskom obrazovanju u Hrvatskoj, u: Hrvatsko školstvo - sadašnje stanje i vizija razvoja, Zbornik radova s okruglog stola održanog 22. siječnja 2008. U Hrvatskoj akademiji znanosti i umjetnosti u Zagrebu (ur. Popović, S.), HAZU, Zagreb, 107-115.

Sl. list RCG", br. 64/02 od 28. 11. 2002, 49/07 od 10. 08. 2007. i 45/10 od 04. 08. 2010.

Službeni glasnik Republike Srbije (2010). Pravilnik o opštim standardima postignuća obrazovni standardi za kraj obaveznog obrazovanja, 5/2010.

Službeni glasnik Republike Srbije (2014). Pravilnik o program završnog ispita u osnovnom obrazovanju i vaspitanju, 12/2014.

Vuk, R., Vranković, B., Šiljković, Ž. (2012) Postignuća učenika iz geografije Hrvatske na ispitima vanjskoga vrednovanja i percepcije učenika o geografiji kao nastavnom predmetu u osnovnoj školi.

Завод за вредновање квалитета образовања и васпитања, (2014). Извештај о реализацији и резултатима завршног испита на крају основног образовања и васпитања у школској 2013/2014. Години.

Завод за вредновање квалитета образовања и васпитања, (2015). Извештај о реализацији и резултатима завршног испита на крају основног образовања и васпитања у школској 2014/2015. Години.

Завод за вредновање квалитета образовања и васпитања, (2016). Извештај о реализацији и резултатима завршног испита на крају основног образовања и васпитања у школској 2015/2016. Години.

Службени гласник РС, бр. 72/2009, 52/2011, 5572013

http://www.mpn.gov.rs/vesti/

http://www.pztz.ba/Page.aspx?idl $1=43$ 